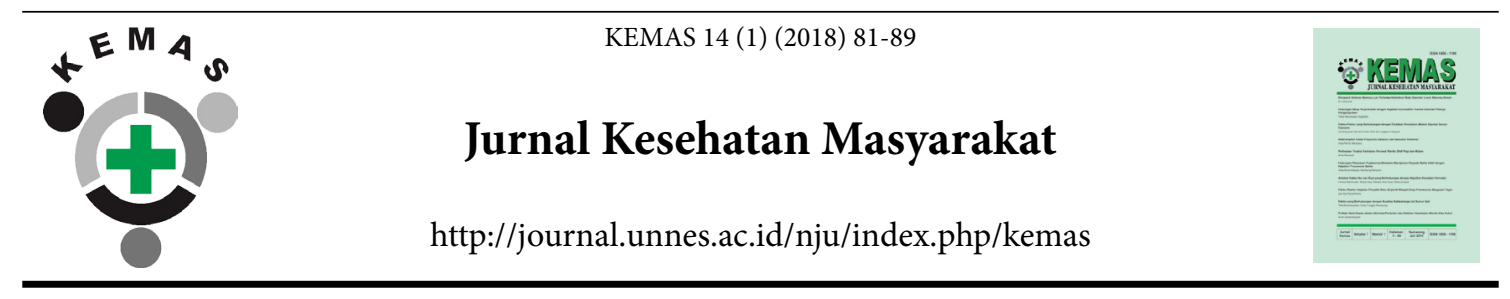

\title{
Analysis on Factors Related with Treatment Behavior of Pulmonary Tuberculosis Patient
}

\author{
Nita Yunianti Ratnasari ${ }^{\bowtie}$, Susana Nurtanti \\ Giri Satria Husada Nurse Academy Wonogiri, Indonesia
}

\begin{tabular}{l} 
Article Info \\
\hline Article History: \\
Submitted Desember 2017 \\
Accepted May 2018 \\
Published July 2018 \\
\hline Keywords: \\
Analysis, Tuberculosis, \\
Compliance treatment \\
\hline DOI \\
https://doi.org/10.15294/ \\
kemas.v14i1.12518
\end{tabular}

\begin{abstract}
The total number of pulmonary tuberculosis cases found in Wonogiri district up to Trimester III in 2017 was 602 new cases. Adherence to patient treatment is one of the decisive factors in the success of therapy, but adherence to treatment by pulmonary TB patients is often low. This study aims to evaluate the compliance of treatment of pulmonary tuberculosis patients in Selogiri District Health Center Wonogiri regency. The design of this study used cross-sectional descriptive analysis with data collector in the form of questionnaire as primary data and patient treatment card (Form TB 01) as secondary data. Population of all pulmonary TB patients treated at Selogiri Public Health Center, registered from January 2016 to December 2017. Sampling by total sampling technique. Result of research from 23 total respondents during treatment showed that the number of respondents who adhere to TB treatment was smaller than the non-compliant respondent, that is 10 respondents $(43,47 \%)$ obedient while respondent did not obey $13(56,52 \%)$. The conclusion of this study there is no relationship between sociodemographic factors, knowledge, drug side effects, history of other diseases, availability of transportation and the role of families and officers with compliance to treatment of pulmonary tuberculosis patients in Selogiri Health Center. This study shows the high rate of non-adherence treatment of lung TB patients.
\end{abstract}

\section{Introduction}

Pulmonary Tuberculosis (Pulmonary $\mathrm{TB})$ is a chronical infection in the community still being main health concern in the world include Indonesia. Pulmonary TB is caused by Mycobacterium tuberculosis bacteria. It become a challange of public health in regional, national and global. Based on World Health Organization (WHO) data in 2013 there were 9 millions world population infected by TB. While in 2014 there were 9.6 millions world population infected by TB. In 2014, number of pulmonary TB mostly were in Africa (37\%), South East Asia (28\%), and East Mediterania (17\%) (WHO, 2015). Pulmonary TB is third rank of killing disease after heart attack and respiratory syndrom on all age group and number one for infectious disease killer. Mortality caused by pulmonary $\mathrm{TB}$ in Indonesia was predicted to reach 61,000 per year (Kementrian Kesehatan RI, 2011).

Based on Global Tuberculosis Control WHO Report 2007, Indonesia was on third rank of largest TB case worldwide $(528,000$ cases). Then in 2009, there was improvement placing Indonesia down to fifth rank $(429,730$ cases) below India, China South Africa and Nigeria. Yet, the matter of TB control still a concern as Indonesia contributes to $5.8 \%$ of global TB cases. With around 430,000 new patient annually and incident rate 189/100,000 
population along with mortality rate 61,000 per year or $27 / 100,000$ population. Beside, TB infected more than $75 \%$ productive age (1554 years old), so the economic loss caused by TB was significant (Kementrian Kesehatan RI, 2011). In term of pulmonary TB control, the compliance to the treatment can be defined as patient having therapeutic medicine compliance to the medicine prescription. The compliance is one of potential factor to increase the relieve of TB patient and incompliance beside reduce patient relieveness also the threat of TB MDR (Bagiada, 2010).

Total of pulmonary TB case finding on District Wonogiri until third quarter (July to September 2017) was recorded as many as 602 new cases. With CDR range up to $30 \%$, while national standard was more than $90 \%$. Therefore new case finding of pulmonary TB on District Wonogiri was considered low. As according to the data from P2 Puskesmas Selogiri District Wonogiri obtained in 2016-2017 there was each 15 and 13 cases of pulmonary TB, whether new case as well as old case (Dinas Kesehatan Kabupaten Wonogiri, 2017)

Considering pulmonary $\mathrm{TB}$ as infectious disease, then the compliance in the treatment is an important matter to be analyzed. Evenmore, there has not been a review of treatment compliance of pulmonary $\mathrm{TB}$ patient and the affecting factors at Puskesmas Selogiri, District Wonogiri, therefore this research was conducted. It is expected that through this research, there will be a review of pulmonary TB patient treatment compliance obtained and affecting factors, furthermore can be used as consideration by medical attendance particularly nurses. The objective of this research is to find out the relation between predisposition factors (sociodemography, knowledge, medicine side effect and other disease history), possibility factors (medicine availability, distance perception and transportation availability), supporting factors (family/Medicine Consumption Supervision/ Pengawas Minum Obat (MCS/PMO) role) and TB care attendant with pulmonary TB patient treatement compliance at Puskesmas Selogiri, District Wonogiri.

Method

This research is an analysis descriptive cross-sectional study using questionare as primary data colection tool and patient treatment record (Form TB 01) as secondary data. This research was taken place at Puskesmas Selogiri in November to December 2017 on pulmonary TB patients had been treated for 2 months or more.

The population was all pulmonary $\mathrm{TB}$ patient of Puskesmas Selogiri, District Wonogiri listed from January 2016 to December 2017. Sampling technique used was total sampling since number of population was less than 100 thus all the population was included as research sample. Data collection was done by home visit to the patients house. The number of pulmonary TB patients listed at Puskesmas Selogiri in 2016 and 2017 were 15 and 13 patients. Yet not all patients could be taken the data for several reasons like the patient had been deceased, itinerated, moving out to other city, change adress and address subscribed was not found.

The data descriptively analyzed were sex, age, education, job, monthly income, knowledge, medicine side effect, other illness history, medicine availability, distance perception, transportation availability, family /PMO role, TB treatment attendant role at puskesmas and treatment compliance of pulmonary $\mathrm{TB}$ patient. While the bivariate correlation analysis to find out the relation between those factors with pulmonary $\mathrm{TB}$ patient treatment compliance status was by Chi Square and Fisher Exact Test. Those data were analyzed by SPSS Statistic 16 program.

\section{Result and Discussion}

The sociodemographic characteristic of pulmonary TB patient studied consisted of sex, age, education, job and monthly income. The patients of Puskesmas Selogiri willing to be respondents were 23 persons consist of new and old (cases) patients. The respondents were 14 male $(60.86 \%)$ and 9 female (39.13\%). The proportion of male was higher than female. This is aligned with Erawatyningsih et al., (2009) found out male respondents were larger than female due to heavy load work, lack of rest and unhealth life style like smoking and drinking.

Monthly income does not affect pulmonary TB. This is aligned with Sejati \& Sofiana (2015) study, mentioned there was no relation between economic status with 
TB incident at Puskesmas Depok 3, District Sleman. It means economic status variable does not significant statisticly yet biologically does.

The evaluation on respondent's knowledge based on their ability to answer the questions of pulmonary $\mathrm{TB}$ disease and treatment. The questions regarding pulmonary TB consisted of cause, symptoms and infection way of pulmonary TB. As the question regarding pulmonary TB treatment consisted of how many pellets each take, medicine taking frequence, advised medicine taking time, duration and the consequence when the medicine did not consumed completely.

Based on the analysis of 23 respondents, 2 persons (8.69\%) considered to have very well knowledge, 11 respondents $(47.82 \%)$ were well knowledge, 4 respondents (17.39\%) had sufficient knowledge and 1 respondent (4.34\%) had poor knowledge regarding pulmonary $\mathrm{TB}$ disease and treatment. This result indicated that most of the respondents had known regarding pulmonary TB disease and treatment. From direct observation, it was assumed due to the patients had been given a health counseling by $\mathrm{TB}$ treatment attendant at the puskesmas when first diagnozed to have pulmonary TB. After the patient understand about the sickness and the treatment, it was expected tthe patient will regularly follow the treatment program. This is aligned with Nugroho (2011) research stating the knowledge regarding TB disease was an important part in health promotion to achieve a community or individual having health behavior by preserve health so that being spared from TB disease. Well and complete knowledge regarding $\mathrm{TB}$ disease and the treatment are related with act taken by someone in the treatment as the awareness increase to complete the procedure. Beside related with act, knowledge also related with perception that TB disease is a harmful and infectious one.

Based on research result on 23 respondents, the side effect of Anti Tuberculosis Medicine/Obat Anti Tuberkulosis (OAT) was perceived by 12 respondents (52.17\%) while the rest 11 respondents $(47.82 \%)$ stated no side effect of OAT. Though the perceiving of side effect, did not cause the respondents to suspend the treatment.

Thepossibility of OAT sideeffectshouldbe communicated to the patient so that the patient does not feel restless. Every patient is advised to report every complaint or the symptoms of OAT side effect to the TB treatment attendant of puskesmas and not allowed to suspend the treatment by their self. The research by Bagiada \& Primasari (2010) stated that the side effect of OAT perceived by the patient caused many of them suspended the treatment. Monitoring of TB treatment side effect once conducted by Munir et al., (2010) obtaining 21 persons (20.8\%) complained regarding digestion disorder, 4 persons complained about liver disorder (4.0\%), 1 person experienced hearing disorder (1.0\%) and 9 persons complained joint ache $(8.9 \%)$. The side effect of TB-MDR mostly did not recorded in polyclinic status as many as $66(65.3 \%)$ so that when checked out the status on joint ache status, only 1 laboratory result obtained examining patient's uric acid.

The occurance of other disease caused many medicine need to be taken by the patient. Beside, the possibility of toxicity and the side effect increase. This become an inhibitor in patient therapy completion. Based on the research, of 23 respondents, 5 persons $(21.73 \%)$ having other disease history other than pulmonary TB obligate the patients to take other medicine, like diabetes mellitus, hypertension. While the rest 18 respondents (78.26\%) stated did not have other disease history.

Based on interview to 23 respondents, same answer obtained. All 23 respondents $(100 \%)$ said that the OAT always available at the puskesmas and can be obtained every time the respondents came to be treated. This was indicated the procurement of OAT at Puskesmas Selogiri District Wonogiri had been sufficient.

Based on research result to 23 respondents, 5 persons $(21.73 \%)$ declared the distance from home to puskesmas was near. While perception of respondents stating the distance from home to puskesmas was medium to far were 14 persons $(60.68 \%)$ and 4 persons (17.39\%).

Transportation availability was evaluated based on respondent's perception to available or not the vehicle used to health facility (puskesmas/public health center). Based on research result to 23 respondents, most of 
them stated the transportation always available as many as 16 respondents $(69.56 \%)$. While 7 respondents (30.43\%) stated the transportation rarely available.

The role of a PMO is highly required to ensure the regularity of pulmonary $\mathrm{TB}$ patient treatment until complete. Based on data of patient treatment record (form TB $01)$, all respondents (100\%) have a PMO from own family member. Therefore, PMO role considered as an effort to support pulmonary TB Patient treatment included in family role at home with same purpose. The role or action evaluated was consisted of remind the patient to regularly consume the medicine and undisruptive, reminding the patient to come or to be controled and sputum re examination as scheduled, encouraged to cure, assisted with treatment fund, advised to take more rest, provided the patient with nutritious food and cleaned the house and environment well.

Based on analysis result to 23 respondents, a view obtained regarding supported family/PMO role as many as 12 respondents $(52.17 \%)$. While the rest stated that family/PMO role were quite support and less support each 4 respondents (17.39\%) and 7 respondents $(30.43 \%)$. The importance of family/PMO role also stated in Nugroho (2011) research result, the presence of PMO was highly important to supervise and monitor patient medical treatment. From the result can be assumed the absence of PMO role can lead TB patient to suspend the treatment.

In this research, the action or role of $\mathrm{TB}$ treatment attendant at puskesmas evaluated from the attitude during the treatment given to pulmonary TB patient, giving information regarding the importance of regular treatment until it complete, explained the proper medicine consumption rule and possible side effect, the willingness to listen to patient complaint and provided the solution and the attendant's role to give health counseling to patient's family. Those were service given by health attendant in the effort to support the pulmonary TB treatment program.

Based on analysis result to 23 respondents, view obtained was the respondents felt the role of TB treatment attendant at puskesmas could be cathegorized as supportive to the treatment as many as 15 respondents (65.21\%). While the rest felt quite supportive and less supportive as many as 3 respondents (13.04\%) and 5 respondents $(21.73 \%)$.

From the result, the number of respondents comply to pulmonary $\mathrm{TB}$ treatment were smaller than the incomply. The comply respondents were 10 persons (43.47\%) while the incomply 13 respondents (56.52\%). Mostly the reason stated by comply respondents was the confidence to be cured by regularly treated beside the support from family members and complete information from TB treatment attendant at puskesmas. The firm motivation of the patient would result the discipline in medicine consumption. One of main concern in TB case treatment in how to motivate the patient to complete the treatment according to determined time. This can be affected by lack of patient knowledge regarding the disease and how to cure it, less satisfied service of healt facility management, culture factor, etc (Sarwani et al., 2012).

Number of medicine should be taken was related with patient usage to the medicine and played the role as treatment sustainability determinant. If the patient does not take OAT on the determined time, then can be assured the patient did not take the medicine regularly (incomply), therefore there would be a tretment suspend (drop out) on the patient. As so, the OAT taking to Puskesmas oftenly been done by patient's family due to job or physical condition reason. Beside, the TB treatment attendant also proactively called the patient when found out not take the medicine on scheduled time. Meanwhile, the uncomplience of the patient in treatment program can be caused by several reasons like forgot to consume, lazy to consume the medicine at one or other time, went out town, busy to work, sputum was difficult to be taken out, etc.

Relation between sociodemographic factors with pulmonary tb patient treatment compliance were evaluated with Chi Square Test for age, education and job. As for sex and education were analyzed with Fisher Exact Test. Age, sex and ethnicity/race were related with patient's compliance on several places. Yet for this research whether Chi Square Test or Fisher Exact Test indicated none of sociodemographic 
Table 1. Crosstab Sex and Monthly Income with Treatment Status

Relation Between Sex and TB Patient Treatment Compliance Status

\begin{tabular}{llllll}
\hline & Value & Df & \multicolumn{2}{l}{ Asymp. Sig. Exact Sig. } & $\begin{array}{l}\text { Exact Sig. } \\
(2 \text {-sided })\end{array}$ \\
& & & $(2$-sided $)$ & (1-sided) \\
\hline $\begin{array}{l}\text { Pearson Chi-Square } \\
\text { Continuity Correction }\end{array}$ & $.878^{\mathrm{a}}$ & 1 & .349 & & \\
$\begin{array}{l}\text { Likelihood Ratio } \\
\text { Fisher's Exact Test }\end{array}$ & .256 & 1 & .613 & & \\
$\begin{array}{l}\text { Linear-by-Linear Association } \\
\text { N of Valid Cases }\end{array}$ & .878 & 1 & .349 & .417 & .306 \\
\hline
\end{tabular}

Relation Between Monthly Income and TB Patient Treatment Compliance Status

\begin{tabular}{|c|c|c|c|c|c|}
\hline & Value & $\mathrm{df}$ & $\begin{array}{l}\text { Asymp. Sig. } \\
\text { (2-sided) }\end{array}$ & $\begin{array}{l}\text { Exact Sig. } \\
\text { (2-sided) }\end{array}$ & $\begin{array}{l}\text { Exact Sig. } \\
\text { (1-sided) }\end{array}$ \\
\hline Pearson Chi-Square & $.140 \mathrm{a}$ & 1 & .708 & \multirow{6}{*}{1.000} & \multirow{6}{*}{.537} \\
\hline Continuity Correctionb & .000 & 1 & 1.000 & & \\
\hline Likelihood Ratio & .140 & 1 & .709 & & \\
\hline Fisher's Exact Test & & & & & \\
\hline Linear-by-Linear Association & .134 & 1 & .714 & & \\
\hline $\mathrm{N}$ of Valid Casesb & 23 & & & & \\
\hline
\end{tabular}

Table 2. Relation of Knowledge with Pulmonary TB Patient Treatment Compliance

\begin{tabular}{lrrrr}
\hline & Value & df & Asymp. Sig. (2-sided) & .922 \\
Pearson Chi-Square & $.915^{\mathrm{a}}$ & 4 & & .864 \\
Likelihood Ratio & 1.286 & 4 & .550 \\
Linear-by-Linear Association & .357 & 1 & \\
N of Valid Cases & 23 & & & \\
\hline
\end{tabular}

a. 9 cells $(90,0 \%)$ have expected count less than 5 . The minimum expected count is, 43 .

factor was related with pulmonary tb patient treatment compliance.

This is indicated by all probability value larger than 0.05 . The analysis shows that the variation of sex, age, education, job and monthly income did not affect the TB patient treatment compliance. This is aligned with Setiarni et al., (2011) research mentioning statistically the relation between economic level and pulmonary TB incident on mature was not significant or not related.

Other studies also mentioned similar result. Sex, age, marital status, education and socioprofesional group membership are not significantly related with patient compliance. Research result by Sianturi (2014), stating there was no relation between sex and pulmonary TB reccurence at BKPM Semarang with $\mathrm{p}$ value $=0.782(p>a 0,05)$. Based on the research, pulmonary TB reccurence was higher on female (53.9\%) than male $(46.1 \%)$. This could be due to outdoor activity causing same outdoor exposure between male and female. Meanwhile according to Dotulong et al., (2015), said age group 15-55 years old had high mobility so that the potention to be exposed by pulmonary tubercolosis microbacterium was higher.

Based on analysis result, respondents having very well and enough knowledge had same compliance status. This is aligned with the expectation that patient having the knowledge or had understood regarding the disease and treatment would be given would comply the program. Then to find out the relation between knowledge and pulmonary tb patient treatment compliance, the Chi Square Test was applied. The result indicated there was no relation between knowledge and pulmonary tb patient treatment compliance status, with probality value higher than $0.05(\mathrm{p}=0.922)$.

This result was different from Erawatyningsih et al., (2009) research, saying 
Table 3. Cross Tabulation Medicine Side Effect with Pulmonary TB Patient Treatment

\begin{tabular}{|c|c|c|c|c|c|}
\hline & & & Complian & e Status & \\
\hline & & & Incomply & Comply & lotal \\
\hline & No & Count & 5 & 8 & $\overline{13}$ \\
\hline & & Expected Count & 7.3 & 5.7 & 13.0 \\
\hline & Yes & Count & 8 & 2 & 10 \\
\hline Side Effect & & Expected Count & 5.7 & 4.3 & 10.0 \\
\hline Total & & Count & 13 & 10 & 23 \\
\hline & Expected Count & 13.0 & 10.0 & 23.0 & \\
\hline
\end{tabular}

Table 4. Relation of Medicine Side Effect with Pulmonary TB Patient Treatment

\begin{tabular}{|c|c|c|c|c|c|}
\hline & Value & Df & $\begin{array}{l}\text { Asymp. Sig. } \\
\text { (2-sided) }\end{array}$ & $\begin{array}{l}\text { Exact Sig. } \\
\text { (2-sided) }\end{array}$ & $\begin{array}{l}\text { Exact Sig. } \\
\text { (1-sided) }\end{array}$ \\
\hline$\overline{\text { Pearson Chi-Square }}$ & $1.051^{\mathrm{a}}$ & 1 & .305 & \multirow{6}{*}{.414} & \multirow{6}{*}{.273} \\
\hline Continuity Correction ${ }^{\mathrm{b}}$ & .365 & 1 & .546 & & \\
\hline Likelihood Ratio & 1.058 & 1 & .304 & & \\
\hline Fisher's Exact Test & & & & & \\
\hline Linear-by-Linear Association & 1.005 & 1 & .316 & & \\
\hline $\mathrm{N}$ of Valid Cases ${ }^{\mathrm{b}}$ & 23 & & & & \\
\hline
\end{tabular}

a. 1 cells $(25,0 \%)$ have expected count less than 5 . The minimum expected count is 4,78 .

b. Computed only for a $2 \times 2$ table

there was significant effect of knowledge to treatment incompliance. The lower the knowledge then the more incomply the pulmonary TB patient to come to be treated, this relation had positive corelation coefficient value. This also stated by Pasek \& Satyawan (2013) that TB patient having well knowledge regarding TB had possibility to comply the treatment 19.71 times higher than patient who did not $(\mathrm{OR}=19,71$, CI95\% 1,69 until 229,17).

The many number of medicine should be taken and the toxicity also the side efect could be obstructing factor in patient therapy completion. Based on analysis result, the respondents experiencing OAT side effect were more incomply as many as 8 persons (34.78\%) compare to comply respondents as many as 2 persons $(8.69 \%)$. The respondent did not experiencing OAT side effect were more comply as many as 8 persons ( $34.78 \%$ ) compare to comply respondents as many as 5 persons (21.73\%).

To find out relation between medicine side effect with TB patient treatment compliance the Fisher Exact Test was used on table 1x2, due to 1 cell containing expected count less than 5. The result was $\mathrm{p}=0.414$ which higher than
0.05 meaning there was no relation between medicine side effect with TB patient treatment compliance status.

Relation indicating insignificancy between medicine side effect with treatment compliance means someone going through pulmonary $\mathrm{TB}$ treatment program whether experiencing the side effect or not, did not affect the respondent to regularly comply the treatment. This was confirmed by all patients explanation stating they never stop the OAT consumption neglecting the side effect. This was assumed due to the attendant at puskesmas had previously informed the possibility of OAT side effect and necessitate the patient to report the side effect to the puskesmas and emphasized the treatment should not be ceased by the patient self. Beside, the OAT side effect experienced by respondents was suspected light and acceptable by the body.

This is different from Erawatyningsih et al., (2009) research result, stating there was significant negative relation between medicine side effect to treatment incompliance of pulmonary TB patient. It meant the more complain the patient had, the more incompliance the patient to the treatment. 
Table 5. Relation of Other Disease History with Pulmonary TB Patient Treatment Compliance

\begin{tabular}{|c|c|c|c|c|c|}
\hline & Value & $\mathrm{df}$ & $\begin{array}{l}\text { Asymp. Sig. } \\
\text { (2-sided) }\end{array}$ & $\begin{array}{l}\text { Exact Sig. } \\
\text { (2-sided) }\end{array}$ & $\begin{array}{c}\text { Exact Sig. } \\
\text { (1-sided) }\end{array}$ \\
\hline Pearson Chi-Square & $.710^{\mathrm{a}}$ & 1 & .400 & \multirow{6}{*}{.618} & \multirow{6}{*}{.367} \\
\hline Continuity Correction ${ }^{\mathrm{b}}$ & .111 & 1 & .739 & & \\
\hline Likelihood Ratio & .705 & 1 & .401 & & \\
\hline Fisher's Exact Test & & & & & \\
\hline Linear-by-Linear Association & .679 & 1 & .410 & & \\
\hline $\mathrm{N}$ of Valid Cases ${ }^{\mathrm{b}}$ & 23 & & & & \\
\hline
\end{tabular}

The Chi Square test result to find out the relation between other disease history with patient treated with ATM compliance determined as not valid due to $50 \%$ cell having expected value less than 5 . Therefore the Fisher Exact Test was used. The result indicated there was no relation between other disease history with pulmonary TB patient treatment compliance with probability $\mathrm{p}=0.618(>0.05)$.

From previous studies, the complexity of the treatment and other disease history had positive corelation with treatment incompliance (Awusi et al., 2009). The other disease history obligated patient to consume various medicine at one time or different time everyday. The plenty medicine should be consumed and variations of rule could confuse the patient and feel saturation thus potentially result incompliance to the treatment program.

Different than previous research, on this one the other disease history was not proven to be related with OAT user compliance. This was confirmed by the finding of respondent going through diabetes and hypertension. Above result showed the other treatment for disease other than pulmonary TB does not a complicated matter for the patient. This was assumed due to the patient had been used to OAT consumption schedule and instruction consisted of 2 or 4 kind of medicines in one capsule proven to assist the patient in OAT consumption. Beside there was possibility of patient awareness to higher risk if those diseases were not treated properly.

The relation between Anti Tuberculosis Medicine (OAT) at Puskesmas with pulmonary TB patient treatment compliance could not be analyzed statistically since the data obtained were homogenous. This was caused by same answer from all respondents, the medicine always available at puskesmas. So there was not any variation in the answer and considered as constant variable.

One of the factor affecting the individual/ community health achievement is health facility reachability. Distance from home to health service facility is an inhibitor factor to utilize the health service and affects the treatment compliance of the patient. Based on analysis result, respondents with near distance from home to puskesmas mostly incomply as many as 5 respondents (21.73\%). For respondents with medium distance mostly comply as many as 8 respondents (34.78\%) compare to incomply ones as many as 6 respondents $(26.08 \%)$. As for respondents with far distance were equal between the comply and incomply patients which were 2 respondents each $(8.69 \%)$

To find out the relation between distance perception with pulmonary TB patient treatment compliance the chi square test was used. The result was probability value $p=$ $0.083(>0.05)$, this meant there was no relation between distance perception with pulmonary TB patient treatment compliance. The significant relation between distance and the compliance was caused by the low compliance to re examine the sputum to the puskesmas as scheduled. This was estimatedly caused by the cost spent to reach the puskesmas like transportation cost and lost of time for person prioritize the job (trading/business).

This is aligned with Erawatyningsih et al., (2009) research, mentioning there was not significant effect of home distance to the treatment incompliance of pulmonary $\mathrm{TB}$ 
patient. Home distance from health facility or puskesmas does not a determining factor of patient incompliance to the treatment, this was due to the puskesmas location on subdistrict Woja could be reached easily since available and expeditous transportation. This was different with Fitriani (2013) stating pulmonary TB patient with far home distance or more than 5 $\mathrm{km}$ of puskesmas did not come to be examined and taken care at the puskesmas so that they were unfiled in medical record.

Based on analysis result, the respondents stating the transportation to went to the puskesmas always available were nearly equal between the comply (50.9\%) and the incomply (49.1\%). The Chi Square Test was considered unvalid since there were 2 cell (50\%) expectation value less than 5 so that the Fisher Exact Test was used. The result was probability value $\mathrm{p}=$ $0.650(>0.05)$. This meant there was no relation between transportation availability with pulmonary TB patient treatment compliance, it was suspected that there was other factor causing the incompliance such as cost matter. Although the transportation to go to the health service always available, yet the cost did not. Therefore the patient did not come to be treated (incomply).

To find out the relation between family/ PMO role with pulmonary TB patient treatment compliance the Chi Square Test was used. The result was probability value $\mathrm{p}=0.226(>0.05)$. This meant there was no relation between family/PMO role with pulmonary TB patient treatment compliance.

This result showed the family support particularly PMO was highly required to ensure the patient willing to complete the procedure of treatment, considered the time of treatment was quite long (6 months or more). Thus there was potential in an incompliance to the treatment program. In many occation, after consumed the medicine for 2 or 3 months and the patient's complaint was gone, the patient feel health and ceased the treatment and finally result of failure. With PMO assistance, the number of patient ceased the treatment could be decreased to 5\% or even more (WHO, 2015).

This was aligned with Erawatyningsih et al., (2009), stating there was not significant effect of PMO role to incompliance of pulmonary
TB patient, where PMO role factor in the treatment did not result significant effect, since each patient had owned PMO and the role had been maximum in treatment supervision. The different result obtained by Muniroh (2013), showing there was relation between PMO and pulmonary TBC patient relief on puskesmas Mangkang work region with Chi Square Test Result $\mathrm{p}$ value $=0.002(<0.05)$.

Based on analysis result, to find out the relation of TB treatment attendant role with pulmonary TB patient treatment compliance by Chi Square Test, the result was $\mathrm{p}$ value $=0.372$ $(>0.05)$. This meant no relation between health attendant at puskesmas role with pulmonary tb patient treatment compliance. Every pulmonary TB patient came to the puskesmas was estimated to get same service (attitude/ counseling) from the health attendant. Yet the satisfactory of the patient did not always same between one and another thus affected the compliance. As mentioned by Basuki (2009), the patient satisfactory on service given by health attendance would affect the patient compliance to the programmed therapy. The result of research by Awusi et al., (2009), said the well or poor knowledged TB treatment attendant had equal opportunity to find pulmonary TB patient.

\section{Conclussion}

Based on analysis result on 23 respondents, the respondents comply to pulmonary TB treatment were lower compare to the incomply ones. The comply respondents were 10 persons $(43.47 \%)$ while the incomply reached 13 persons (56.52\%).

The predisposition factors consisted of sociodemographic, knowledge, medicine side effect, other disease history, transportation availability, distance perception, family role and health attendant role. From the analysis result, none of them had relation with pulmonary TB patient treatment compliance at Puskesmas Selogiri District Wonogiri.

\section{Acknowledgement}

The acknowledgent goes to the Head of Puskesmas Selogiri District Wonogiri along with the staffs for the completion of the research process. Gratitude is also expressed to patients of pulmonary $\mathrm{TB}$ on subdistrict Selogiri, particularly them who have participated. 


\section{Reference}

Awusi, RYE., Saleh, Y.D., Hadiwiyono, Y., 2009. Faktor-Faktor yang Mempengaruhi Penemuan Penderita TB di Kota Paru Provinsi Sulawesi Tengah. Berita Kedokteran Masyarakat, 25(2).

Basuki, Endang S. 2009. Konseling Medik: Kunci Menuju Kepatuhan Pasien. Majalah Kedokteran Indonesia, 59(2).

Bagiada, I.M., \& Primasari, N.L.P., 2010. FaktorFaktor yang Mempengaruhi Tingkat Ketidakpatuhan Penderita Tuberkulosis dalam Berobat di Poliklinik DOTS RSUP Sanglah Denpasar. Jurnal Penyakit Dalam, 11(3).

Departemen Kesehatan RI, 2008. Pedoman Nasional Penanggulangan Tuberkulosis Cetakan ke-2. Jakarta

Dinas Kesehatan Kabupaten Wonogiri, 2017. Jumlah Temuan Kasus Baru Tuberculosis Paru Triwulan III, P2P Dinkes Kab. Wonogiri.

Dotulong, J.F., Sapulete, M.R., Kandou, G.D., 2015. Hubungan Faktor Risiko Umur, Jenis Kelamin dan Kepadatan Hunian Dengan Kejadian Penyakit TB Paru Di Desa Wori Kecamatan Wori. Jurnal Kedokteran Komunitas dan Tropik, III(2).

Erawatyningsih, E., Purwanta., Subekti, H., 2009. Faktor-Faktor yang Mempengaruhi Ketidakpatuhan Berobat Pada Penderita Tuberkulosis Paru. Berita Kedokteran Masyarakat, 25(3).

Fitriani, E., 2013. Faktor Resiko yang Berhubungan Dengan Kejadian Tuberkulosis Paru. Jurnal Kesehatan Masyarakat, 2(1).

Kementerian Kesehatan RI, 2011. Pedoman Pelaksanaan Hari TB Sedunia 2011. Ditjen Pengendalian Penyakit dan Penyehatan Lingkungan. Jakarta.

Muniroh, N., Aisah, S., Mifbakhuddin., 2013.
Faktor-Faktor yang Berhubungan dengan Kesembuhan Penyakit Tuberculosis (TBC) Paru di Wilayah Kerja Puskesmas Mangkang Semarang Barat. Jurnal Keperawatan Komunitas, 1(1), pp.33-42.

Munir., S.M., Nawas, A., Soetoyo, D.K., 2010. Pengamatan Pasien Tuberkulosis Paru dengan Multidrug Resistant (TB-MDR) di Poliklinik Paru RSUP Persahabatan. Jurnal Respirasi Indonesia, 30(2).

Nugroho, R.A., 2011. Studi Kualitatif Faktor yang Melatarbelakangi Drop Out Pengobatan Tuberkulosis Paru. Jurnal Kesehatan Masyarakat, 7(1), pp.83-90.

Pasek, M.S., \& Satyawan, I.M., 2013. Hubungan Persepsi dan Tingkat Pengetahuan Penderita TBdengan Kepatuhan Pengobatan di Kecamatan Buleleng. Jurnal Pendidikan Indonesia, 2(1).

Sarwani, D., Nurlaela, S., Zahrotul, I.A., 2012. Faktor Resiko Multidrug Resistant Tuberculosis (MDR-TB). Jurnal Kesehatan Masyarakat, 8(1), pp.60-66.

Sejati, A., Sofiana, L., 2015. Faktor-Faktor Terjadinya Tuberkulosis. Jurnal Kesehatan Masyarakat, 10(2), pp.122-128.

Setiarni, S.M., Sutomo, A.H., Hariyono, W., 2011. Hubungan antara Tingkat Pengetahuan, Status Ekonomi dan Kebiasaan Merokok dengan Kejadian Tuberkulosis Paru pada Orang Dewasa di Wilayah Kerja Puskesmas Tuan-Tuan Kabupaten Ketapang Kalimantan Barat. Jurnal Kesehatan Masyarakat, 5(3).

Sianturi, R., 2014. Analisis Faktor yang Berhubungan dengan Kekambuhan TB Paru (Studi Kasus di BKPM Semarang Tahun 2013). Unnes Journal of Public Health, 3(1).

WHO (World Health Organization), 2015. Treatment of Tuberculosis Guidelines Fourth edition. Geneva: World Health Organization. 